\title{
SOCIAL DISAFFECTION AMONG DEPRIVED GROUPS
}

\author{
DANIEL KATZ \\ Institute for Social Research, \\ Universing of Michigan
}

\author{
BARBARA GUTEK \\ University of California- \\ Los Angeles
}

\author{
EUGINIA BARTON \\ Institute for Social Research, \\ Universin of Michigan
}

\begin{abstract}
One test of societal cleavages is the extent of differences in the population between subgroups such as race, social class, or generations. at three levels: nationalism. support for the political system, and satisfaction with aspects of every day living. National sample data indicate no clear marks of division on these three dimensions in the U.S. for groupings based upon income. education, occupation. age, or sex. The grearest potential cleavage is racial, for here there are differences berween Blacks and Whites. consistent though not great, at all three levels. Various groups are tied into the system in different ways. People in the lower strata are stronger than managerial groups in their nationalism and evaluation of administrative agencies but lower on their confidence in national political leadership.
\end{abstract}

The problem of societal integration, the social bonds which tie people to one another and to the larger collectivity, keeps reappearing in theory and research over the years. Recently, it has been approached from the negative side of the picture in the revival of concepts of alienation and anomie on the individual level and in concepts of cleavage lines in society at the collective level. It is interesting that the basic notions at both the individual level and the collective level derive from Marx in his description of alienation and of a conflicted class society. Marx may have had his weaknesses as an economist (though his successors are not much more impressive in their predictions), but his insights as a social psychologist were profound. At the individual level it was Marx who described the frustrations of workers arising from their estrangement from their jobs when they no longer owned the tools of their craft and when their craft skills were destroyed by job fractionation and routinization. At the collective level it was Marx who regarded sandomly distributed frustrations as less significant for social action than attitudes of discontent which cumulate in groupings of the population where mutual 
reinforcement can occur and class consciousness can develop. For him the potential for linking dissatisfaction with change programs came from people sharing the same common fate. As they struggled to improve their lot they became aware of their friends and of their enemies. And for Marx, the lines of cleavage determining the common interests of given groups were determined by the institutional arrangements concerning the distribution of power and wealth.

As survey research methods developed with the growth of social psychology in the U.S. it became possible to test predictions about social divisiveness. Early studies of political behavior and of social and economic attitude found good correlations between socioeconomic status and political preference and radicalism and conservatism as Marx anticipated. There were clear and unmistaken differences between workers and owners on many issues which seemed to justify the notion of cleavage lines. V. O. Key (1961) pointed out that these differences were not on radicalism and conservatism as general value orientations, but as they related to economic issues. There were high negative correlations between socioeconomic status and suppor for social welfare legislation, for unemployment insurance, for minimum wages, even for govemment ownership of banks.

With the acceptance of New Deal measures by both Democrats and Republicans in the years which followed, the correlations between socioeconomic status and relevant political and economic attitudes began to decline. Philip Converse (1958) documented this decline in showing that the correlations between presidential voting and occupational status had dropped from .44 in 1948 to a mere .14 in 1956.

Status crystallization can be viewed, however, in a broader context than the politization of socioeconomic groupings. There can be significant differences in beliefs, motivation, and behavior characteristics of segments of society; for example, confidence in the political system and trust in national leadership, or degree of satisfaction with the workings of the economic system. These differences can make for social disintegration and fumish the basis for subsequent status crystallization along political lines. Moreover. the lack of political class divisiveness during the fifties and sixties may be related to a period of economic prosperity and growth which may not be replicated in the foreseeable future. Finally, there may be serious lines of divisiveness in society which do not follow the Marxian predictions but embrace variations in age or generation, sex, religion, and race. The turmoil of the sixties did not array owners and managers against the working class. 
If we turn to societal integration recognizing other lines of division than social class, we need also to recognize other aspects of people's values and behavioral orientations on which there is consensus besides economic conservatism and radicalism. Three areas of values and behavioral orientations are worthy of study in this connection. One is support for the political system: i.e., confidence in national political leadership. trust in the administrative agencies of govemment, and satisfaction with the way public agencies handle one's own problems. A second is symbolic nationalism, namely emotional attachment to the symbols representing the nation. At the level of nationalism people can be tied together in their attachment to their identity as a nation state or they can be bound together in their own subgroup as a separatist movement. A third area consists of satisfactions with life at the pragmatic level of income, jobs, neighborhood, family, friends, and community. People can be staunch citizens, supportive of their society because of high levels of satisfaction with their way of life with respect to their jobs, their neighborhood, their community, the opportunities for their children. The many studies on social indicators and quality of life by the Institute for Social Research yield data on levels of satisfaction among subgroupings in the U.S. Richard Flacks (1974) has taken this into account in his statement: "The overall legitimacy of the system rests on the emotional commitment of the majority to their every day lives, and their perception that every day possibilities and meanings are supported and not infringed by the 'system.'

In addition to suppor or lack of support for ongoing social systems of the three types just described, there has been considerable interest in generalized expressions of disaffection more at the level of personality characteristics. A high level of distrust of others, for example, may characterize some individuals and though it may have developed because of social deprivations, it may not be tied to any specific social setting. For some researchers alienation and anomie are regarded in the same way, namely, as generalized personality characteristics (McClosky \& Schaar, 1965), though other investigators prefer to have some system frame of reference for these concepts (Form, 1975). In any event it is necessary to recognize that people may be generally hostile or apathetic in many social situations and their reactions are diffuse and not fixated on specific targets. Our assumption is that the linkage of aggression to the causes of frustration may occur over time and under certain conditions, but people in a complex society do not automatically analyze and identify the causes of their problems in precise fashion. The attack upon specific social institutions is a later, and not an inevitable, 
step in the process. Hence we shall give special attention in later pages to personal distrust as an intervening variable between conditions of deprivation and attitudes of rejection or hostility toward particular aspects of the social and political system.

\section{METHOD}

\section{Data}

The data with which we are concemed came primarily from a study of people's encounters with public bureaucracy, a national sample survey of the Michigan Institute for Social Research in the field in the spring of 1973 (Katz. Gutek. Kahn. \& Barton. 1975). This investigation dealt both with people's experiences with govemment agencies and with more general attitudes toward the political system. Two other sources of data are also utilized: (1) the investigations of Withey and Andrews (1976) on social indicators consisting of three national surveys in 1972 and 1973, and (2) the national survey of Campbell, Converse, and Rodgers (1975) of 1971 on quality of life. The study of bureaucratic encounters furnished information in the first two areas described above -support for the political system and symbolic nationalism-and, in addition, contained a measure of interpersonal trust. The other surveys (Withey \& Andrews, 1976; Campbell, Converse, \& Rodgers, 1975) inquired in considerable detail into the third area of pragmatic satisfactions but also contained some questions relevant to support for the political system.

More specifically, the bureaucratic study provided data which fell into three major clusters in the domain of political support:

1. Satisfaction with own experience with governmental agencies: People were asked about their last episode with a public office, about the problems they experienced, the faimess of treatment, the effort and considerateness shown by agency personnel, the promptness and efficiency of service, etc. An additive index was constructed to give a summary measure of satisfaction.

2. General evaluation of administrative agencies: Three separate indices were constructed to measure confidence in public bureaucracy based upon item intercorrelations (Katz, Gutek, Kahn, \& Barton, 1975). These subindices were:

a. General attitudes toward bureaucracy such as the efficiency and faimess of govemment offices in general. 
b. Rejection of negative stereotype, e.g., "many of the people who are getting welfare payments are really cheating the government."

c. Helpfulness of government workers, e.g., "most of the people who work for governmental offices work hard and try to do a good job."

3. Confidence in national political leadersin: The five questions used here are those which Arthur Miller and his colleagues (1972, 1973) found clustered together as a single factor in repeated surveys going back to $1958 .^{1}$ Miller and his colleagues have labelled this factor political cynicism.

The measure of symbolic nationalism in the bureaucratic study comprised the answers to four questions which emerged as a single factor in a factor analysis of the data and which have been suggested by previous studies of nationalism² (Katz, Kelman, \& Vassiliou, 1969; DeLamater, Katz, \& Kelman, 1969).

The study of bureaucratic encounters also utilized a measure of interpersonal trust consisting of three questions, again taken from the studies of Miller and his colleagues $(1972,1973) .^{3}$ These three questions have appeared as a single factor consistently in repeated surveys since 1958.

For the third area related to alienation, the individual's satisfactions with his way of life, we shall utilize some of the findings of the two investigations of social indicators. The results of the one investigation (Campbell et al., 1975) are based upon the responses of a national sample during July and August of 1971. The second investigation consists of three separate national surveys conducted in May 1972, November 1972, and April 1973. (Withey \& Andrews, 1976). Specifically, the questions inquired into the individual's satisfaction with the following types of life situations: (1) economic well being, including feelings about family income, taxes, cost of living, fringe benefits, financial security. standard of living, and housing; (2) the job, including satisfaction with the work itself, with the conditions of work, and with co-workers; (3) the neighborhood and community, as a place to live, the people who live in the area, the services and facilities available such as doctors, clinics, hospitals, transportation, shopping facilities, police and fire protection, street maintenance, the schools in the area; (4) recreation: chances for relaxation, facilities for recreation, time for doing what one wants to do, entertainment from TV, radio, movies, local events, etc; (5) family and friends: people you see socially, things 
you do with friends, chances to know congenial people, organizations you belong to, own family life, things family does together, feelings about spouse, about children, close adult relatives; and (6) self-image: satisfactions with accomplishments in life, in achieving success, selfdevelopment, independence to do what one wants, social competence, etc.

The Withey and Andrews (1976) studies did not include a few questions in the political domain. namely: satisfaction with the way the national government is operating, the way the local govemment is operating, what the government is doing about the economy, and the way the police and courts are operating in their area. The Campbell et al. (1975) survey inquired also into attitudes of interpersonal trust and attitudes toward life in the U.S.

\section{Analysis Plan}

Our plan is to look at four possible cleavage lines in American society, namely social class, sex, generational or age differences, and race, and to see to what extent there is polarization within subgroupings on various dimensions of system support (the political system, nationalism, and satisfaction with various aspects of daily life situations). If we find, for example, that blue-collar workers are considerably higher in dissatisfactions with many features of their way of life than other occupational groups, if they are of different political convictions, have less confidence in national political leaders, find government bureaucracy has no solution for their problems, and are less patriotic in sentiment than other occupational groups, we have grounds for speaking of them as alienated as individuals and as a potential collective threat to the established social order. Similarly, we would speak of a generational gap only if there are significant differences among age grqups on a number of these dimensions.

So much of the discussion of social conflict of warring groups has been based upon newsworthy events as presented in the mass media, or upon uncontrolled observations, or upon poorly selected and unrepresentative samples. If we are concerned with societal cleavages, then there is a great advantage in approaching the problem with samples representative of the national population. Moreover, such an approach has the advantage of making comparisons over time on the same groupings, which can not be done when measures come from a sample where the relationship to known characteristics of a given universe lack specification. We selected the four particular potential lines of cleavage that 
we did because they have been associated in our society with controversy, turmoil, and proposals for social change. In fact, the significant social movements of the last two decades have been associated with the young, the Blacks, and women. We have included social class because we are not as confident as some of our conservative colleagues that economic problems of unemployment, recession, and inflation are superficial, fleeting phenomena.

\section{RESULTS}

\section{Social Class}

Let us look first at socioeconomic status as fumishing clues for divisiveness in our society. It is true that the findings of Philip Converse on the lack of status crystallization in the U.S. in 1956 have been confirmed in studies of political orientation and behavior in almost all elections since that time. Congressional voting does show a slightly higher correlation with socioeconomic status than presidential voting. When subjective class identification (or the class with which people identify) is used to replace objective measures of economic status, the correlation improves very little. In the study of bureaucratic encounters, strength of party identification similarly showed a very modest correlation between income and considering oneself a weak, moderate, or strong Democrat or Republican (.25).

Income and support for the political system. The bureaucratic encounters study used four measures of socioeconomic status: income, education, occupation, and position in the labor force (unemployed, retired, etc.) When income is used as an indication of deprivation, there is no consistent pattem of relationships between economic status and political support in the various indices we employed. On some measures the poor are less supportive than the affluent and on other measures the reverse is the case (Table 1). There is a clear relationship between income groups with respect to national political leadership in that the affluent, those over $\$ 15.000$, are most supportive and those with incomes under $\$ 10,000$ the least supportive. But the very poor (under $\$ 3,000$ ) do not differ from other relatively low groups (up to $\$ 10,000$ ) in amount of distrust. Our measure of confidence in national political leadership consisted of five questions about the ability, integrity, motivation, and effectiveness of government leaders in Washington. Even before Watergate there was an erosion of confidence in Washington which was 
TABLE 1

Income Related to Types of System Support

\begin{tabular}{|c|c|c|c|c|c|c|c|c|c|c|c|c|}
\hline \multirow{4}{*}{ insos: } & \multirow{2}{*}{\multicolumn{2}{|c|}{ 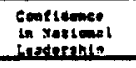 }} & \multicolumn{6}{|c|}{ 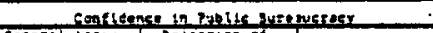 } & \multirow{2}{*}{\multicolumn{2}{|c|}{ 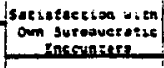 }} & \multirow{2}{*}{\multicolumn{2}{|c|}{ 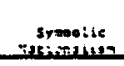 }} \\
\hline & & & \multirow{2}{*}{\multicolumn{2}{|c|}{ 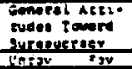 }} & \multirow{2}{*}{\multicolumn{2}{|c|}{ 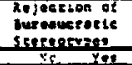 }} & \multirow{2}{*}{\multicolumn{2}{|c|}{ 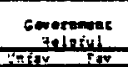 }} & & & & \\
\hline & antov & ras & & & & & & & rintay & +30 & تص & بحتبد \\
\hline & 32.68 & 26.48 & $20 . n$ & 29.18 & 14..02 & เ3. $\pi$ & 19.48 & 28.06 & $16 . \pi$ & 20.62 & $20 . n$ & 20.62 \\
\hline $3.000: 06.999$ & 29.1 & 23.1 & 23.2 & $36 .+$ & 20.6 & 12.0 & 14.2 & 40.0 & 16.4 & \$. & 16.7 & 22.5 \\
\hline $3.000 \times 07,000$ & 26.3 & 22.9 & 23.5 & 21.2 & 23.2 & 20.6 & 26.5 & 21.3 & 20.1 & 21.2 & 15.1 & 16.7 \\
\hline $7,500 \mathrm{~kg} 9, \mathrm{men}$ & 39.6 & 26.0 & 29.2 & 20.5 & 19.5 & 0.3 & 22.2 & 26.1 & $1 \mathrm{sin}$ & 20.0 & 21.6 & 17.3 \\
\hline $10.000=12.64$ & 20.7 & 23.6 & 20.2 & 22.1 & 20.2 & 13.1 & 19.7 & 69.2 & 16. & 19.2 & (6.) & 22.7 \\
\hline 12.900 to 16.991 & La.1 & 27.7 & 25.2 & 6.2 & 19.J & 16.0 & 22.6 & $\therefore 3.2$ & 16.1 & L2.1 & 20.6 & 16.5 \\
\hline $15.000=19.60$ & 19.3 & 31.2 & 19.1 & 10.5 & 10.5 & 07.1 & 20.6 & 35.9 & 12.1 & 19.1 & 9.5 & 19.1 \\
\hline 20.0000 & 16.1 & 3s.. & 21.0 & H.1 & 22.1 & 36.3 & 22.0 & 36.7 & 9. & 14.1 & 16.8 & 13.1 \\
\hline
\end{tabular}

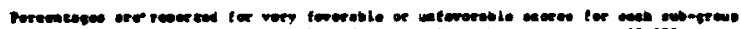

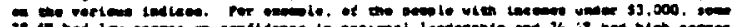

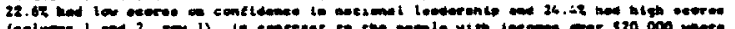

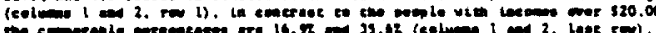

finally arrested in the fall of 1974. But the rate of decline did not differentiate the poor from other income groups (Miller, Brown, \& Raine, 1973). All income groups were affected and in roughly the same degree, with the affluent more positive than the poor in 1958 and again in 1973.

When we turn to general evaluations of public bureaucracy, however, we find that on some questions the poor are more favorable than other income groupings, specifically in finding the governmental agencies and personnel helpful (Table 1). If the questions shift to accepting or rejecting stereotypes about bureaucracy, the relationship changes with the poor more critical than the well-to-do. When the questions call for overall evaluation of the functioning of governmental agencies it is the middle-income groups which tend to be more cynical.

On satisfaction with own experience with public office, the lowerincome groups were much more positive in their assessments than were the middle-income groups (Table 1). There were large and significant differences in this respect between those making under $\$ 5,000$ a year and those making between $\$ 5,000$ and $\$ 15,000$. The top-income groups were also favorable to the agencies they had encountered, but not as uniformily as the poor.

On the measures of suppor for the political system, then, we find that economic deprivation does not indicate clear lines of class cleavages. The poor are more negative in their evaluation of some aspects of the system than the affluent but more positive toward other aspects.

Emotional attachment to national symbols, the second area to which we referred, showed only slight differences for the various income 
TABLE 2

Education Related to Types of System Support

\begin{tabular}{|c|c|c|c|c|c|c|c|c|c|c|c|c|c|}
\hline \multirow[b]{3}{*}{ Edusecter } & \multirow{2}{*}{\multicolumn{3}{|c|}{ 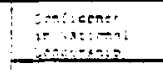 }} & \multicolumn{6}{|c|}{ 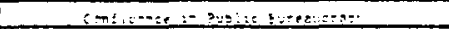 } & \multirow{2}{*}{\multicolumn{2}{|c|}{ 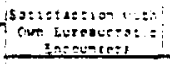 }} & \multirow{2}{*}{\multicolumn{2}{|c|}{ 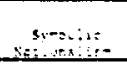 }} \\
\hline & & & & \multirow{2}{*}{\multicolumn{2}{|c|}{ 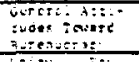 }} & \multirow{2}{*}{\multicolumn{2}{|c|}{ 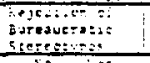 }} & \multicolumn{2}{|c|}{$\begin{array}{c}\text { covernoct: } \\
\text { neitit? }\end{array}$} & & & & \\
\hline & & 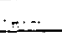 & $\therefore$ & & & & & $\frac{M i}{-i n}$ & $\frac{i t !}{12 !}$ & $r \leq$ & 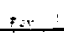 & 10 & $\because \ldots-$ \\
\hline i vents te ient & ! & $: \because z$ & 20.5 & $\because 4.5$ & 32.7 & 10.0 & $14.5 !$ & $: 3.7$ & $2: 2.4$ & :...5: & $3 s=$ & $13.5=$ & $23.1=$ \\
\hline c-i: reess & : & $\because \div$ & 2t. 6 & $\therefore a$ & $2 \pm .1$ & $2: 1$ & $\therefore:=$ & $\therefore 3$. & 363 & $: 3:$ & $26-$ & $: 75$ & 29.3 \\
\hline Mirn 5 :nenl & & $\therefore:=$ & $2 \pi$ & $24 .+$ & $2^{n} .:$ & $\therefore-$ & $\therefore$ a : & $16 . t$ & $\ldots i$ & $\because:$ & 19.6 & is . - ? & $2: 2$ \\
\hline p.sen-e? & & $\because 4$ & $\because$ & $\because *$ & $\therefore 2$. & $\because \because$ & 16. & $? 4:-5$ & $\cdots$ & $\therefore ! .:$ & $2 ! . ;$ & $1 \ldots$ & : $9 .:$ \\
\hline seme $c=i 1$ ere & & $\therefore=$ & $\because=$ & te .: & $12 . t$ & 2 & $\because 6$ & $=3 . t$ & $3-0$ & 10 & $212=$ & 21.: & :3: : \\
\hline E. A. $=$ & i & $1 \ldots$ & $99:$ & $: 9.1$ & $15=$ & Ie ? & $\therefore \ldots$ & 23.9 & 3. & $\therefore \therefore$ & $: 2.5$ & $\therefore=$ & 11.1 \\
\hline
\end{tabular}

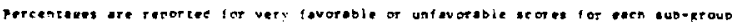

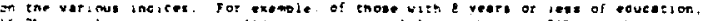

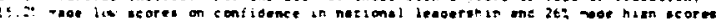

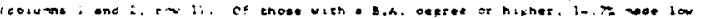

groups (Table 1). There were no consistent tendencies among the various income groups in their nationalistic attitudes, e.g., respect for the flag and the national anthem, teaching patriotism in the schools, and a tough line toward draft evaders.

Education and support for the political system. Though education is positively comelated with income it conceivably could be a more sensitive measure of social status and. therefore, might show stronger patterns of relationship with measures of system support than does income. This expectation was not realized, however. with respect to confidence in national political leadership. Income was a better predictor than education (Table 2). Both those with the least education (eight years or less) and those with the most education (a college degree or more) are the most trustful of national political leaders. In attitudes toward administrative agencies the same pattern appeared for educational groups as for income groups in a greater acceptance of negative stereotypes about bureaucracy among the deprived. And just as low income was correlated with finding the government helpful, so too is low education. Evaluation of the functioning of public bureaucracy does show a stronger relation with education than with income, with the most poorly educated being the most supportive. When individuals report about their own experiences with service agencies, it is the poorly educated who are the most positive. Three times as many of those with eight years or less of schooling report favorable as opposed to uniavorable experiences, whereas among those with high school or higher training about the same proportion report the reverse. 
Nationalism showed little relationship with income but there was a clear tendency for the poorly educated to be more nationalistic than the well educated. Some 23 percent of those in the low-education category (eight years or less of schooling) against 11 percent of college graduates were very high on the patriotism index (Table 2).

Education, then, does not divide the nation into politically disaffected and satisfied groups on the basis of amount of schooling. Lack of education can be a source of deprivation in a society in which access to positions of prestige. power, and material rewards is determined in part by school credentials. On the other hand, education leads to higher expectations and satisfaction in life is a result both of achievement and of level of aspiration. Our findings show that it is the poorly educated who are most positive in their suppor of the existing system.

Occupation and support for the political system. Occupational groups showed some differences in degree and type of support for the political system, but no group shows a consistent pattem of disaffection. All white-collar occupations, whether professional or clerical, do differ from blue-collar callings in showing more confidence in national leadership and greater rejection of negative stereotypes about bureaucracy (Table 3). But this dichotomy of occupational groupings breaks down on general evaluation of bureaucracy with the semiskilled blue collar workers resembling professional people in being the most critical of governmental functioning. Nor does the dichotomy hold when people talk about the helpfulness of govemment, for on these questions the unskilled blue-collar worker and the white-collar clerical people are the most supportive. In evaluating their own experiences with service agencies. the professional people resemble the skilled and semiskilled blue-collar workers in being the most positive of the occupational groupings. On nationalism it was the managerial people rather than blue-collar workers who scored the highest on symbolic patriotism with the professionals showing the lowest scores. It was the managerial group, too, which expressed the greatest confidence in national political leadership. Thus, if we know a person's occupation we can predict very little about his alienation from the political system. If he is a professional, he is somewhat more likely to be supportive but in a sophisticated fashion; if he is a manager he is somewhat more likely to give uncritical support at a general level; if he is a blue-collar worker he is somewhat more likely to be appreciative of specific governmental services; and if a white-collar clerical worker, even less can be ventured about a differential pattern of response. 
TABLE 3

Occupation Related to Types of System Support

\begin{tabular}{|c|c|c|c|c|c|c|c|c|c|c|c|c|}
\hline \multirow[b]{3}{*}{ Decuostio } & \multirow{2}{*}{\multicolumn{2}{|c|}{ 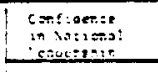 }} & \multicolumn{6}{|c|}{ 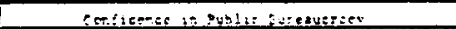 } & \multirow{2}{*}{\multicolumn{2}{|c|}{ 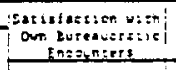 }} & \multirow{2}{*}{\multicolumn{2}{|c|}{$\begin{array}{l}\text { sumelise } \\
\text { ontemuliz- }\end{array}$}} \\
\hline & & & \multirow{2}{*}{\multicolumn{2}{|c|}{ 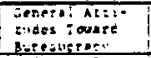 }} & \multirow{2}{*}{\multicolumn{2}{|c|}{ 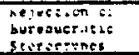 }} & \multirow{2}{*}{\multicolumn{2}{|c|}{$\begin{array}{c}\text { covernment } \\
\text { belofit } 1\end{array}$}} & & & & \\
\hline & $n-i s y$ & $i n$ & & & & & & & $\ln x$ & 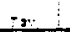 & . & $\therefore \quad$. \\
\hline Prof peses onel & $2 r .28$ & $26.6=$ & 21.37 & $12.0 . !$ & 16.67 & $19.6:$ & 29.12 & 34.65 & 16.12 & 19.22 & $20 .=$ & 10.12 \\
\hline Manosere & 18.0 & $21 .-$ & 26.3 & 14.6 & 18.3 & $:::$ : & 14.0 & 29.; & $1: n$ & $1: \div$ & 12.2 & $2 c .3$ \\
\hline Cieracal boles & 20.1 & 27.8 & $: 2 .:$ & 20.8 & $2: .:$ & $23 .:$ & Is,: & : i & $16 . \mathrm{c}$ & 16.2 & 27.0 & 13.6 \\
\hline craterens & $3 E .2$ & $2 * .4$ & $\because 7.6$ & $2: .1$ & $2 t .6$ & 8.: & 23.: & 4e.2 & 12.6 & 23.0 & 19.5 & 19.5 \\
\hline Operetzve & $2 n .3$ & 22.1 & 30.3 & 18.8 & 23.9 & 13.2 & $\because: 3$ & 38.3 & $: x . y$ & 31.6 & 27.1 & 20.8 \\
\hline Leborer: & $2 t+4$ & 23.2 & 23.2 & 23.2 & 22.3 & 11.4 & $1: .7$ & $36 . t$ & 26.7 & 25.9 & 26. & 17.3 \\
\hline rarmets & 3.0 & 23.0 & 16: : & te. & 25.0 & 10: : & $\because:-$ & 22.0 & $22 . t$ & 26.0 & 3.6 & 23.0 \\
\hline Hoomerkinf & 16.0 & 31.8 & 12.0 & 25.1 & 10. & 19.2 & 15.2 & t. & 15.1 & 29.2 & Is.? & 23.3 \\
\hline
\end{tabular}

Another measure of socioeconomic deprivation is working statuswhether unemployed, employed, or outside the labor force or retired, disabled, housewives, and students. Here we came closer to an alienated group in that negative responses for the unemployed outweigh positive responses on confidence in national leadership, nationalism, and evaluation of own experience with service offices. Moreover, the unemployed were lower than the employed and those not in the working force on four of the six measures of system support we have been discussing, and tied for last place on the remaining two measures (Table 4). The greatest system support came from the groups not in the labor force-the retired, the disabled, students, and housewives. It is true that the number of unemployed we are dealing with is small because we are working with a national sample. But the findings are internally consistent and intuitively plausible. Since our study was in the field there has been a 50 percent increase in unemployment and the prospects indicate that unemployment will continue to be a problem for some time to come. Hence, it should be emphasized that the disaffected people are not those low in income outside the labor force, but those who are in the labor force and have lost their jobs. Of all our measures of socioeconomic status only unemployment gives a clear relationship with dimensions of political system-support.

Our findings thus indicate that objective measures of deprivation such as income, education, and occupation do not reveal any deprived group as significantly alienated on measures of political system-support (with the exception of the unemployed as just noted). It is interesting that the various groups are tied into the system in different ways. The people in the lower strata are stronger than the managerial groups in their favorable account of their own experiences with service agencies and higher 


\section{TABLE 4}

Woriking Status 2s Related to Types of System Support

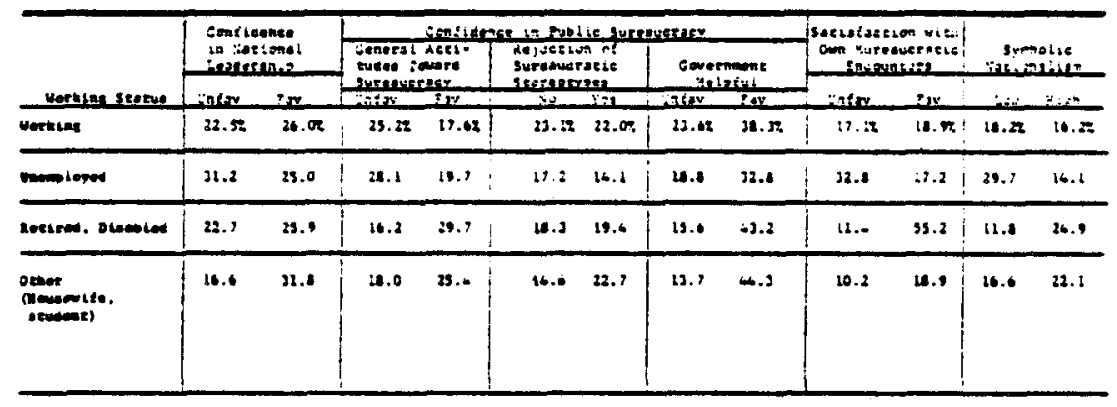

in their nationalism than the professional group. No one group from the three socioeconomic categories, however, depars consistently from the others in negative attitudes toward the political system.

Relative deprivation and support for the political system. There has been a growing body of literature which recognizes the importance of relative rather than absolute deprivation (Hyman \& Singer, 1968). Even Marxian theory gave some recognition to the relativity of need satisfaction in describing the psychological impact of depression after a boom period. It also saw the skilled workers, rather than the lumpen proletariat, as the advance guard of the revolution. The measures we have been considering of income, education, and occupation are differences in an objective sense. They tell us that certain people are better off than others but not whether different income groups compare themselves with one another. Individuals do not necessarily use as a reference group those who are better off than they are. The poor may not consider themselves disadvantaged if they compare themselves with other poor people or with their parents' earlier poverty. Hence, we used as a measure of relative deprivation the discrepancy score between education and income. Our assumption was that the college graduate in the middle-income category would be more likely to be disaffected than would the person who had not completed high school. ${ }^{4}$ In general, the index based upon discrepancy between education and income did show some of the expected relationship to the various measures of system support, but not in robust fashion (Table 5). The relationships do not reverse themselves as was the case for amount of income where the poor were sometimes more supportive of the system than were the middleincome groups. The poor, defined in absolute terms as those making 
TABLE S

Relative Deprivation Related to Types of System Support

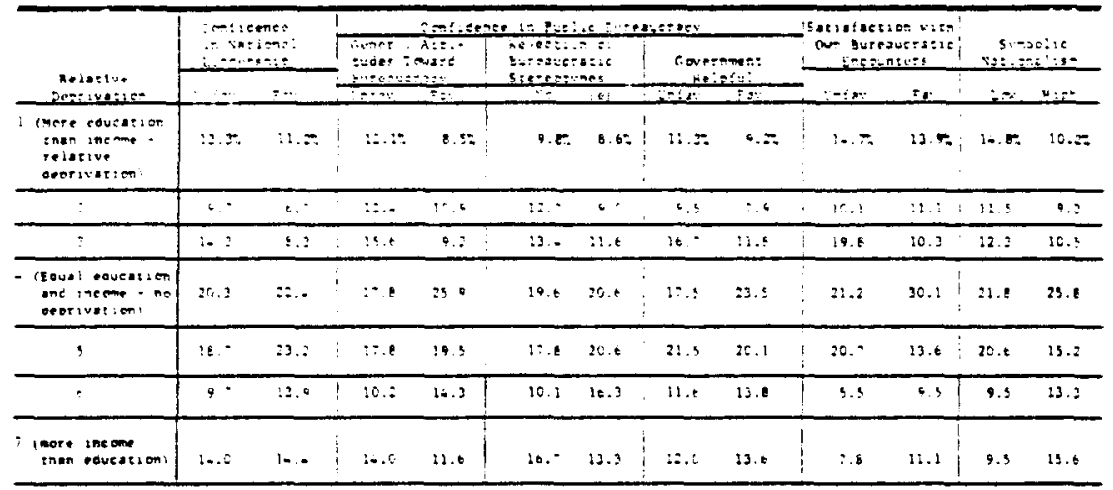

under $\$ 5.000$. found the govemment helpful. were satisfied in their experience with public agencies. and in general evaluated public bureaucracy more favorably than those better off. When we turn to a measure of relative deprivation, however, and compare people with incomes below their educational status with people with incomes appropriate to their education. we find the expected differences for three dimensions of support for the political system. The relatively deprived are less happy about their experience with bureaucracy. They find government less helpful and they evaluate bureaucracy less favorably. There is a slight tendency for the people with more education than income to be more positive than the relatively deprived, but the most satisfied groups consist of those with incomes congruent with their education. On acceptance of stereotypes about bureaucracy and on confidence in national political leadership there are no consistent differences among these subgroupings. On symbolic nationalism there are no clear. consistent trends. Over all these results do afford some evidence for Lenski's hypothesis (1956) of status congruence but the meagre nature of the support is similar to the findings of other investigators who report contradictory and marginal findings (Jackson \& Curtis, 1972; Broom \& Jones, 1970).

In summary, our measures of absolute deprivation-namely income. education, and occupation do not show the expected correlations between amount of deprivation and amount of disaffection on most dimensions of system support. In fact. the relationships are ofien reversed. with less alienation among the poor and uneducated groups compared to the affluent and well educated. Relative deprivation, however, is a more 
promising basis for seeking differences in system support. In general, people whose schooling is consistent with their income are likely to be the most supportive of the political system. Though these differences are slight, they might assume larger proportions with more precise measures of relative deprivation. For example, there are people whose income is not high in relation to their education but who do not feel deprived because they are in occupational callings of their choice. Hence, it would be helpful to have a large enough sample to control on occupation in considering relative deprivation. Moreover, the standards which individuals use to evaluate their earnings come not only from their educational level, but from other sources such as living standards of friends, of parents, of other family members, of colleagues, and of own past history. Feelings of frustration may have to be assessed in relation to various types of relative deprivation. As these types multiply, the concept of relative deprivation becomes much less useful for prediction for the collectivity.

Social class and pragmatic satisfactions. Detailed inquiries into people's frustrations and satisfaction with their way of life did show some clear differences along lines of social class (Campbell et al., 1975; Withey \& Andrews, 1976). Specifically, people of low socioeconomic status were more dissatisfied than those of high socioeconomic status with financial security, family income, standard of living, wages, cost of necessities, their married life, security from theft, physical needs, health, chances for a good job, degree to which they were achieving success, and amount of fun and enjoyment. Withey and Andrews go on to say:

The rather bleak picture is only broken by absence of differences in evaluations of interpersonal relationship outside of the family and in almost all of the evaluations of community, neighborhood, house, etc. The low SES group also reports better than average satisfaction with their time to do things and they report less dissatisfaction than higher SES groups with housework and work around the house. In addition. the low SES category members report more satisfaction than average or higher SES people with the conditions of the natural environment, the informational media, and political leaders. One can make a clear case that low SES people are not more critical than others of government, government services, and public institutions of information and entertainment. It is their personal situation that arouses their ex- 
pressed dissatisfaction. They appear to be preoccupied and overwhelmed with the clear problems of being poor. (1975)

Thus the poor do react to economic deprivation with dissatisfaction about economic matters. concern about health and physical needs, discouragement about finding a better job. Nevertheless, this relationship between deprivation in absolute terms and dissatisfaction with economic conditions was not great, namely a correlation between size of family income and satisfaction with standard of living of .25 (Campbell et al.. 1975). What discouragement about economic matters does exist does not seem to rub off on their feelings about their neighborhood, their community, their relations with their friends. Nor does it rub off on feelings toward the political system. There is as much, if not more, satisfaction with national and local government among low as high income groups-which confirms the findings from our study of bureaucratic encounters.

Disaffection along class lines is confined to the specifics of economic deprivation and as yet has not generalized to political expression in which targets for attack are identified by the needy. Potential lines of cleavage do exist and continuing economic recession may produce cracks in the political system. But there is a tremendous reserve of positive forces for system unity and it will take unusual folly on the part of political leaders to consume this reserve. On the other hand, we should not underestimate the capacity of our leadership for colossal errors and for the repetition of error.

\section{Sex Differences}

In comparing the attitudes of men and women, let us go back to the data from the study of bureaucratic encounters to look at possibie differences with respect to support for the policy. Though women have been regarded as an exploited and frustrated group in modem society, they seem in no way alienated from the political system. Just as many women as men express confidence in national political leadership, and just as many women as men are nationalistic. Women tend to be slightly more favorable than men in general attitudes toward bureaucracy, to be less accepting of negative stereotypes of bureaucracy, to show positive attitudes toward the helpfulness of government, to have had fewer negative experiences with public office. Both groups are alike on the index of interpersonal trust. 
The Withey and Andrews (1976) study dealing with satisfactions with various life domains found no appreciable differences between the sexes. A similar study of the quality of life (Campbell et al., 1975) makes this concluding statement about sex differences:

We have not been able to find support in our study for the contention that the lives of women are less rewarding than those of men. It is true that we have found some women whose life situation seems more frustrating than that of men, divorced women for example, but we have also seen men whose lives seem less satisfying than those of most women, unmarried men for example. The greatest differences we have found in this study are not between women and men, taken as total populations, but between groups within each sex who live in different circumstances.

Women may be the objects of discrimination in educational, job, and promotional opportunities and the victims of a male-dominated culture, but the dissatisfactions which they may have do not aggregate consistently to produce differences between the sexes in suppor for the political system. It may be that the minority of women who do achieve successful careers are satisfied and those who do not, do not necessarily have that level of aspiration. Or it may be that women do not complain as much as men, even when they are hurting. It could even be that at an earlier period women were more supportive of the status quo than men and the present equivalence shows a decline which will continue over time. Or it may be that questions which deal with satisfaction with job, family, home, friends, and self-development at the pragmatic level, or questions which deal with confidence in political leaders and political instimutions do not really touch the critical areas of the women's liberation movement. Finally, it may be that men and women are dominantly frustrated as individuals and not as members of one sex or the other.

\section{Age Differences}

The new political leftism and the counter culture have had their strengths among the young. Hence, it is instructive to look at a national sample rather than at elite groups to see how age groupings differ in their support for the establishment and its agencies.

In confidence in national political leadership, the 18 to 24 age group does not differ from any other age category save its immediate seniors 
TABLE 6

Age Related to Types of System Support

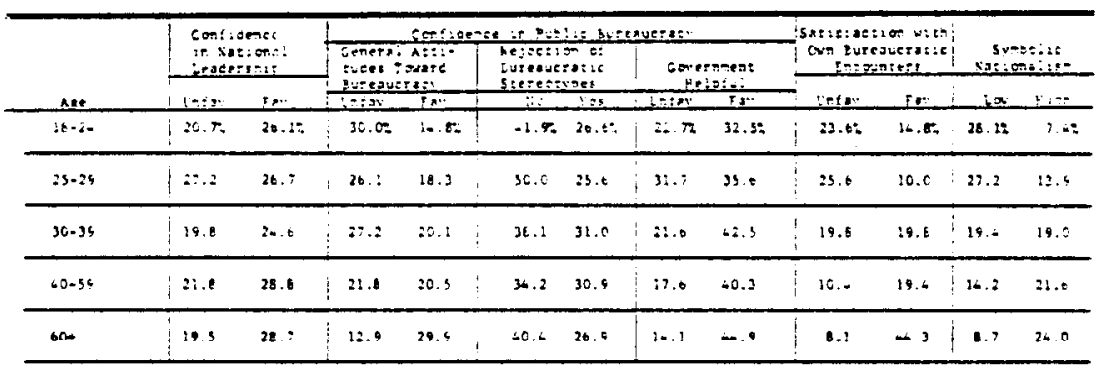

(25-29). The 25 to 29 year olds are less supportive, whereas people at all other ages are more likely to be positive than negative toward national leaders (Table 6).

In general attitudes toward bureaucracy there is a steady progression with age of more favorable assessment. The sharp differences are between the extreme age groups-18 to 24 year olds and those 60 and over-and they are in the expected direction. In accepting negative stereotypes of public bureaucracy these extreme groups come together as equally critical of government offices. The most positive age groups are the people between 40 and 59 and the most negative, those between 25 and 29. Another attitude measure, that govemment is helpful, shows considerably more favorable than unfavorable responses for all age groupings save the 25 to 29 . The oldest respondents ( 60 and over) are the highest in this response ratio. At the experiential level, both groups of young people (18-24 and 25-29) are more dissatisfied with their agency encounters than are those 40 and over. The oldest age group has relatively few dissatisfied people in this respect.

On symbolic nationalism the 30-year division does apply, in that both the 18-24 and 25-29 groups are low in attachment to national symbols, with the 18-24 group being lower that the $25-29$ year olds. Those 30 to 39 are evenly balanced in high and low nationalism scores and the scales tip toward higher scores as age increases. There is support here for the thesis that symbolic nationalism is on the decline in our technological society.

In general, there is suggestive evidence that some of the mechanisms which have worked to tie people to the system in the past are no longer as potent for the newer citizens. The newcomers tend to be lower in nationalism. in general attitudes toward bureaucracy, and in favorable 
encounters with the bureaucracy. Do these findings reflect a change in culture, or are they a function of age? In other words, will they persist as younger people grow older, or will younger people change toward the norms of their parents as time goes by? We do not have definitive answers, but on some of the dimensions we are dealing with cultural change and on the other with transient age differences. For example, the dissatisfactions with specific agencies expressed by young people have to do with their seeking job training and job placement. As these same clients grow older and turn to other agencies for other types of service, their reactions may change. On the other hand, the decline in potency of attachment to symbolic patriotism looks like a stable cultural change. At other times in history, age as such would have predicted more emotional involvement among the young than among the old.

Though young people are in general less supportive of the establishment, age differences are not as consistent or as sharp as to permit labeling any age group alienated or anomic. There is a suggestion in our findings, moreover, that there is less disaffection among the youngest group-the 18 to 24 year category - than among the 25 to 29 age group. This is consistent with the decline in student activism from the sixties to the seventies. When we speak of differences between the young, the middle aged, and the old, we are dealing with percentage variations of a few points. Even where statistically significant, these differences do not account for a great deal of the variance on measures of system support. In the Withey and Andrews study (1975) of satisfactions with various aspects of life situations, age differences did appear but they were not indicative of any real generational gap. For most items, save those related to health, there were slight increases in satisfaction with increasing age. Campbell et al. (1975) also found less satisfaction among young people, but again the differences were not great. These investigations had some evidence to indicate that two opposed processes are at work in producing generational differences. The aging process in itself leads to decreases in feelings of well-being consistent with the biological running down of the organism. The cultural standards of the period in which a generation is socialized can have the opposite effect. Younger people can have higher standards and greater expectations than their parents and so may express greater unhappiness with their education, jobs, and self-development.

Overall, we had expected greater generational differences than have appeared in any of these national sample surveys. It is true that questions about satisfactions with the areas investigated by Withey and Andrews, and Campbeil et al. are not necessarily indicators of political orienta- 
tion. Nevertheless, even the queries about national govemment, local government, the police, and the courts gave a very similar pattern of answers across generational groups.

The revolt of the young is probably much more along lines of cultural lifestyle than along lines of political change. One of the problems in the student activism of the sixties was the attempt to fuse political advocacy and cultural rebellion against conventional restraints. Traditionally the two have not gone together, in that a radical movement requires strict discipline and self-sacrifice of a Puritanical sort. Apparently the attempt to marry the two revolts did not succeed. The new political leftism had little impact but the movement toward a freer life style did. Not insignificant numbers of the older generation were only too happy to accept changes in dress and deportment which gave them greater opportunities for self-expression. In summary, age differences are not a reliable basis for political or social structural change.

\section{Race Differences}

Race is also viewed as an important determinant of integration into the national system. Blacks, Spanish-speaking Americans, and Indians as deprived minorities would not be expected to be as supporive of the existing social order as are members of the white majority. Our results show sizeable differences between Blacks and Whites on a number of dimensions (Table 7). Three times as many Blacks (39 percent) are highly critical of national political leadership as are strongly supportive (13 percent). This is the reverse of the ratio for whites, where 20 percent are highly critical and 28 percent strongly supporive. On the individual items making up this index of confidence in national political leadership, Blacks showed the greatest differences from whites on the two questions: "How much of the time do you think you can trust the government in Washington to do what is right?" and, "Do you think that quite a few of the people running the government are a little crooked, not very many are, or do you think hardly any of them are crooked at all?"

Some 10 percent more of Blacks than of Whites evaluated government agencies very unfavorably and seven percent fewer Blacks thought government agencies helpful. Nonetheless, more biack people responded positively to this question than negatively. In terms of their own experiences, there are slightly more negative than positive responses among blacks, reversing the pattern for whites. 
TABLE 7

Race Related to Types of System Support

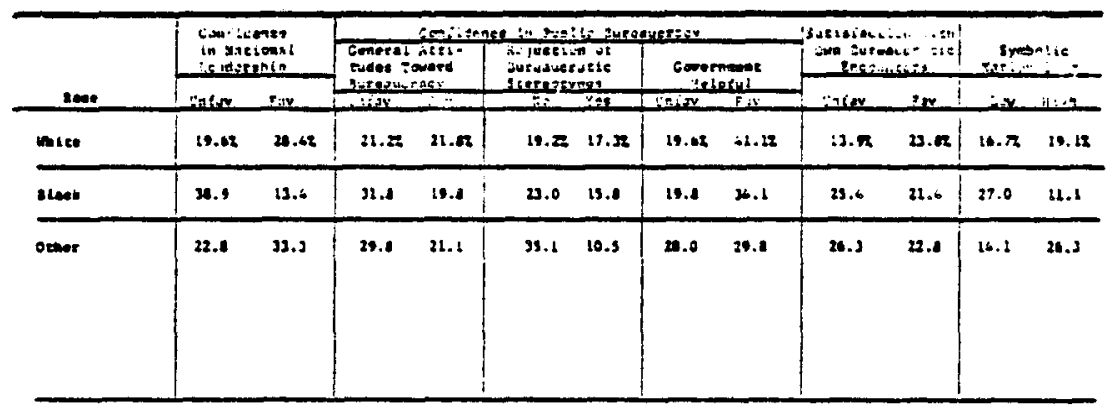

Blacks were also low in symbolic nationalism, with only 11 percent at the high end of the scale. Whites were also low on the nationalism index, with 19 percent making high scores but more of them were in the middle of the scale.

In summary, the Blacks are the most alienated of any of the groups we have examined, though the racial differences are not large. Our group of other racial minorities (Spanish-speaking people and Indians) is too small to yield anything but suggestions about relationships $(N=57)$. These minority individuals resemble Blacks more than Whites in attirudes about lower levels in the system. But they are much closer to the Whites than to the Blacks in confidence in national political leadership and in symbolic nationalism.

Withey and Andrews (1976) found Blacks less satisfied than Whites in some of the domains differentiating the poor from the wealthy, but overall the dissatisfaction of Blacks appeared in many more aspects of life than it did for Whites. The differences between the rich and the poor with respect to family income, standard of living, and financial security are similar to the differences between Blacks and Whites. So, too, are the relative satisfactions expressed about physical needs and health, marriage, chances for getting a better job, and achieving success. Blacks, however, are also more unhappy than Whites about domains which show no correlations with income. Specifically, race is a better predictor than income of dissatisfaction with neighborhood, community, goods and services available, housing, recreation facilities, opportunities to change things, independence and freedom, the way others treat them, the respect they get, faimess of treatment, acceptance and inclusion, the way the national government is run, and the way the local 
government is run. In summary, the disgruntlement of blacks goes beyond their economic plight and is also directed at a discriminatory social environment. There are political overnones as well in their lack of confidence in political leadership.

Blacks, however. showed no differences from whites in their evaluations of their jobs, their co-workers, their friends and acquaintances, their close relatives. their enjoyment of many aspects of their environment. and their feelings of self-worth.

Campbell et al. (1975) also repored greater dissatisfaction among blacks than whites and only part of this could be attributed to differences in economic status.

What, then, are the implications of these findings about differences in system support and life satisfactions among Blacks and Whites? Are we dealing with lines of divisiveness so sharp and so extensive that we can anticipate increased social conflict in the years ahead? Or are there differences similar to the divisions between the newly arrived ethnic groups and the older established population so familiar in American history?

The research results here presented do not indicate deep and sharp cleavages with substantial majorities of whites supporing the system and satisfied with their way of life and substantial majorities of Blacks evaluating the system and their own life satisfactions negatively. On most questions the majority of both groups are positive and the differences between them, though statistically significant, are not great. Moreover. some of these differences are greatly reduced if we control on income or marital status.

What is of concern, however. is the widespread pattern of differences. The greater disatisfaction among the Blacks is to be found not only in economic matters, but in many other aspects of their lives and it does carry over to the political system. It does not matter that some of this discontent can be factored out as related in part to income. Black workers will not make common cause with white workers beyond a specific labor-management dispute if they see themselves as discriminated against and deprived because they are Black. Hence, the extensive differences do suggest continued conflict. We have the sort of reinforcement which is the Coser criss-crossing hypothesis in reverse, namely the accumulation of dissatisfaction in the various roles and members of a single ethnic group. The most direct answer to the problem of social divisiveness comes, however. from trend stidies dealing with black militancy and black separatism. Trend data do show increases in the estrangement of Blacks (Schuman \& Hatchett, 1974), 
increases, moreover, which do not reflect the impact of the current recession since the interviewing took place prior to 1972. Blacks have been more heavily hit than Whites by unemployment. In addition, govemment machinery for helping the disadvantaged has been overloaded and has not really softened the blow in many instances. Some Blacks who had improved their standard of living now face the bitter economic fate of an earlier period. The prediction would be that the ethnic division will sharpen. Blacks are too small a minority to develop a viable separatist movement but the problem of their societal integration will be one of our pressing problems in the years ahead.

\section{Cleavage Lines and Interpersonal Trust}

We have looked at discontent at two levels: (1) social disaffection as evidenced in withdrawal of support from the political system and (2) personal dissatisfaction with specific aspects of everyday living. Our object has been to see whether there is an accumulation of negative affect along objective divisions of income, education, occupation, sex, age, and race. We have not inquired, however, into the relationship between such objective groupings of the population and more personalized reactions. It may well be that the deprivations the individual suffers from being poor or Black or female do constitute frustrations which lead to a generalized personal hostility rather than to aggression against appropriate targets. In a complex social world the first reaction to frustration may be a negative response to the generalized other. David Easton (1965) has theorized that a basic level for social suppor is a sense of political community - a willingness of people to trust one another in cooperation on common tasks. Our closest measure of this variable consisted of three questions on interpersonal trust, which Miller and his associates (1972) had found to be an independent factor among a battery of items dealing with anomie and alienation.

Interpersonal trust shows stronger relationships with potential cleavages lines than do measures of system support (Table 8). Income groups differ significantly with those in the $\$ 15,000 \div$ category, having more than half their number believing that people can be wusted whereas less than one-fourth of those making under $\$ 5,000$ held this belief. Groups intermediate in income are also intermediate in trust. Education shows the same relationship with completion of high school being one turning point in increasing confidence in one's fellows and completing college another tuming point. Occupational groups similarly reveal clear differences with managerial and professional groups the most trusting, with 
TABLE 8

Interpersonal Trust Related to Income and Education

\begin{tabular}{|c|c|c|c|c|c|}
\hline \multirow[t]{2}{*}{ Ineanes } & \multicolumn{2}{|c|}{ Inkerperional Trust } & \multirow[t]{2}{*}{ Educreision } & \multicolumn{2}{|c|}{ intersenenel truet } \\
\hline & 1. & Lut & & $2 x$ & hest \\
\hline Ueder 13.000 & 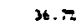 & 25.02 & I yeart or leso & 36.17 & 23.5 \\
\hline 3.000 to 6.099 & 38.1 & 23.2 & 9. Il genre & 30.3 & $2 t .9$ \\
\hline 3.000 to 7.500 & 32.3 & 30.7 & Hagh Sehool & 29.5 & 33.8 \\
\hline 7.500109 .999 & 36.6 & 33.3 & Mith senoot & 29.6 & 34.3 \\
\hline $10.000 \times 012,446$ & 23.6 & 33.3 & some coldege & 29.5 & 62.2 \\
\hline $12,300 \leq 014,000$ & 23.2 & 36.1 & s. a. - & 14.1 & 58.3 \\
\hline 25.000 co 19.999 & 19.1 & -7.1 & & & \\
\hline 20.000 & 19.9 & 36.8 & & & \\
\hline
\end{tabular}

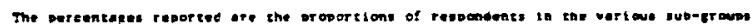

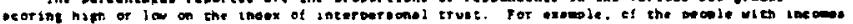

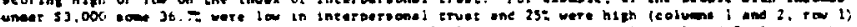

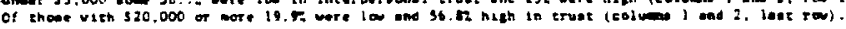

TABLE 9

Interpersonal Trust Related to Occupation and Working Status

\begin{tabular}{|c|c|c|c|c|c|}
\hline \multirow[t]{2}{*}{ Oetuancion } & \multicolumn{2}{|c|}{ Interwersosel Trunt } & \multirow[t]{2}{*}{ Vorktak Stome } & \multicolumn{2}{|c|}{ 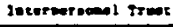 } \\
\hline & 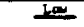 & Dint & & her & With \\
\hline Trof onetionl & 15.7 & 31.27 & Vertust & $29 . \pi$ & 35.32 \\
\hline numeser: & 16.3 & st.1 & Dneselese & 62.2 & 32.8 \\
\hline Elarient 6 seles & $2 i-7$ & 60.1 & metsred. disatiod & 22.7 & 33.6 \\
\hline Cratemen & 33.6 & 22.1 & 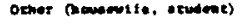 & 25. & 37.3 \\
\hline Omeretes & 40.1 & 23.0 & & & \\
\hline Leterer: & 36.7 & 22.6 & & & \\
\hline Termert & 32.2 & 39.2 & & & \\
\hline Hencombtat & 24.4 & 37.1 & & & \\
\hline
\end{tabular}

over three times as many managers and professionals making high scores as making low scores. White-collar workers are also on the positive side of the scale but not as much so. Blue-collar workers, on the other hand, tend to be distrustful and this is just as true of the skilled as of the unskilled. Being unemployed makes a difference, but not as large a difference as might be expected (Table 9).

Sex makes no difference in scores on interpersonal trust. Men and women show highly similar distributions. Age, however, is definitely a determinant of confidence that one will not be taken advantage of. The very young (18-24) show a ratio of two to one in their beliefs that people can't be trusted as compared to beliefs that people can be trusted ( 40 percent to 22 percent). Those 60 and over have the same ratio but in the opposite direction ( 20 percent to 40 percent). If we consider all age groups, trust increases progressively from one group to another. In shor, there does seem to be some social reality behind the admonition, 
TABLE 10

Interpersonal Trust Reiated to Age and Race

\begin{tabular}{|c|c|c|c|c|c|}
\hline nen & Interens & . & stove & inkneare & strus \\
\hline $16-24$ & $\frac{10}{3 . x}$ & 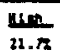 & valces & $\frac{\text { penfer }}{26.02}$ & $\frac{\operatorname{lev}}{3 t . \pi}$ \\
\hline $23-29$ & 32.2 & 21.9 & Deats & 54.0 & 11.2 \\
\hline $20-37$ & 36.0 & x.7 & onerer & 36.6 & 16.0 \\
\hline co-s4 & 26.8 & 4t.2 & & & \\
\hline$\infty+$ & 20.1 & 10.6 & & & \\
\hline
\end{tabular}

"Don't trust anyone over 30," in that young people tend to be much more distrustful than their elders (Table 10).

Race is also clearly related to interpersonal trust. There was a larger margin of difference between Blacks and Whites on this variable than on any of our measures of system support. Fifty-four percent of the Blacks as against 25 percent of the Whites were low in trusting other people and 11 percent of the Blacks compared to 39 percent of the Whites made high scores on the trust dimension (Table 10).

Cleavage lines thus appear more clearly on a general personality dimension such as trusting others than on attitude toward national political leadership, the public bureaucracy, and related items of system support. It may be that the first direct effect of deprivation is to undermine the individual's confidence in people rather than in remote complex cognitive objects like the political system. The frustrated person may not trust the system but what happens to him seems to occur through human agencies and he becomes generally distrustful of others. Moreover, social realities may reinforce this belief in two ways: (1) the poor and uneducated are more subject to crude exploitation by money changers than are the rich and (2) among the poor the scarcity of possessions makes it necessary to be highly protective. In other words, in a competitive society some margin of resources may be a prerequisite to interpersonal trust. This explanation does not hold. however, for age differences in confidence in the faimess of others. But the young, unilike the poor, do not take out their frustrations just in interpersonal distrust. They are also more critical of the political system.

Our interpretation, then, is that the common outcome of social deprivation is a rejection and suspicion of other people. This is a generalized distrust of people as people and not of the part they play in the social system. Whether or not this hostility gets channeled into collective patterns of action oriented toward social change is a later and more 
complex development. Ted Gur (1970) has presented the most comprehensive account of this complexity in calling attention to such factors as the intensity and scope of relative deprivation, the intensity and scope of utilitarian justifications for political violence, the intensity and scope of normative justifications for political violence. and the politicization of discontent.

\section{CONCLUSION}

Lines of societal cleavage in the U.S. based upon divisions according to social class, age, or sex do not reflect sharp differences in attitudes of support for the political system. in symbolic nationalism, or in pragmatic satisfactions with daily life. The one socioeconomic segment which does show greatest signs of disaffection is the unemployed-not those outside the labor force, but those who are unsuccessfully seeking employment. They constitute the one group with consistent negative attitudes toward various aspects of the system. It would follow that unemployment is a much more critical variable for alienation in our society than income, age, or sex. The other strong finding in our study was that deprivation works more to create distrust of other people than of the system itself.

The reason for the failure of social class to show differences in support for the political system also may be related to a redefinition of the left-right dimension in our culture. The working classes, in addition to their traditional and conservative ideology with respect to civil liberties, may also have become conservative with respect to govemmental intervention in other areas as well. They have a vested interest in a status quo in which they have held good jobs and enjoyed a fair standard of living. They do not want government intervening in setting standards for the auto industry, in controlling pollution, in planning environmental programs. These changes can be threatening. It is the better educated and more affluent (excluding the managers) who are more open to such new ideas. Though economic group interest is not dead. the traditionalism of workers and the liberalism of the better educated make for a complex pattern which weakens a correlation, either positive or negative, between socioeconomic status and support for the political system. ${ }^{5}$ Moreover, our measures of dissatisfaction with the functioning of political institutions did not differentiate between the critics of the left and the critics of the right, which would also weaken any correlation between alienation and socioeconomic status. Arthur Miller (1974) has demonstrated that support for political leadership 
comes from the middle of the left-hand continuum and that the people who are on the right are as distrustful of our national leaders as those on the left. The mobilization of workers around a programmatic pattern of reform, as in the thirties, does not appear to be the most likely political outcome in the near future. What could occur is the mobilization of workers around traditional values, which would also have some appeal for the radical right, in other words, a resurgence of populism.

\section{NOTES}

Requests for reprints should be addressed to: D. Katz. Institute for Social Research. University of Michigan. Ann Arbor, MI 48106.

1. The questions follow:

a. How much of the time do you think you can trust the government in Washington to do what is right: just about always, most of the time, or only some of the time?

b. Would you say the government is pretty much run by a few big interests looking out for themselves or that it is run for the benefit of all the people?

c. Do you feel that almost all of the people running the government are smart people who usually know what they are doing, or do you think that quite a few of them don't seem to know what they are doing?

d. Do you think that quite a few of the people running the government are a little crooked. not very many are, or do you think hardly any of them are crooked at all?

e. Do you think that people in the govemment waste a lot of the money we pay in taxes, waste some of it. or don't waste very much of it?

2. The four questions are:

a. What do you think the government should do about young men who evaded the draft? Should they be sent to prison. should they be made to serve their country in some way, or should they be given amnesty-that is, no punishment?

b. If a foreigner visiting this country were to criticize many things about America. what would your reaction be? Would you feel that he is being insulting; that he is just showing bad manners; or would you feel that he has every right to express his own opinion?

c. Do you think that our schools are putting enough emphasis on teaching children to be patriotic Americans?

d. How do you feel about Americans who won't rise when the Star Spangled Banner is being played? Do you strongly approve. approve. don't care, disapprove. or surongly disapprove?

3. The questions follow:

a. Generally speaking. would you say that most people can be trusted. or that you can't be too careful in dealing with people?

b. Would you say that most of the time people try to be helpful, or that they are mostly just looking out for themselves?

c. Do you think most people would try to take advantage of you if they had the chance, or would they try to be fair? 
4. We divided our respondents into seven groups on the basis of income and again into seven groups on the basis of education and the discrepancy score was the difference between the individual's classification on these two variables.

5. House and Mason (1975) came to a similar conciusion after looking at the relationships between a measure of political distrust and other variabies. They write: "In general. the electorate has in recent years sought means of expressing discontent and some pcliticians have sought to address it. but the lack of correspondence berween attitudinal cleavages and demographic and institutional divisions poses difficult problems for those wishing to mobilize or respond to discontent in a way which endures longer than campaign rhetoric" (p. 145).

\section{REFERENCES}

BROOM. L.. \& JONES, F. L. Status Inconsistency and Political Preference: The Australian Case. Americen Sociological Review, 1970, 35, 989-1001.

CAMPBELL, A., CONVERSE, P. \& RODGERS, W. The Qualiny of American Life. New York: Russell Sage, 1975.

CONVERSE, P. The Shifting Role of Class in Political Artitudes and Behavior. In E. Maccoby, T. Newcomb, and E. Hartey (Eds), Readings in Social Psychology, 3rd edition. New York: Henry Holt. 1958. 388-399.

DeLAMATER, J., KATZ. D., \& KELMAN, H. On the Nature of National Involvement: A Preliminary Study in an American Community. Journal of Conflict Resolution. 1969, 13, 320-357.

EASTON, D. A Systems Analysis of Political Life. New York: John Wiley \& Sons, 1965.

FLACKS, R. Making History vs. Making Life: Dilemmas of the American Left. Working Papers for a New Society, July 1974.

FORM, W. H. The Social Consoruction of Anomie: A Four Nation Study of Industrial Workers. American Journal of Sociology, 1975, 80, 1165-1191.

GURR, T. Why Men Rebel. Princeton, N.J.: Princeton University Press, 1970.

HOUSE, J. S., \& MASON, W. M. Political Alienation in America, 1952-1968. American Sociological Review, 1975, 40, 123-147.

HYMAN, H. H., \& SINGER, E. Readings in Reference Group Theory and Research. New York: Free Press. 1968.

JACKSON, E. F., \& CURTIS, R. F. Effects of Verrical Mobility and Starus Inconsistency: A Body of Negative Evidence. American Sociological Review, 1972, 37, $701-713$.

KATZ, D., KELMAN, H., \& VASSILIOU, V. A Comparative Approach to the Study of Nationalism. Peace Research Sociery, Papers XIV, 1969, 1-13.

KATZ, D., GOTEK, B.. KAHN, R., \& BARTON E. Bureaucraric Encounters. Ann Arbor, Mich.: Institute for Social Research, University of Michigan, 1975.

KEY, V. O. Public Opinion and American Democracy. New York: Knopf, 1961.

LENSKI. G. E. Status Crystallization: A Non-vertical Dimension of Stanus. American Sociological Review, 1954, 19, 405-413.

MeCLOSKY, H., \& SCHAAR, J. H. Psychological Dimensions of Anomy. American Sociological Review; 1965, 30, 1440.

MILLER. A. Political Issues and Trust in Government: 19641970. American Political Science Review, 1974, 68, 951-972. 
MILLER, A. H. Political /ssues and Trust in Government: 1964-1970. Paper delivered at 1972 Annual meeting of the American Political Science Association. Washington. D.C.. 1972.

MILLER, A. H., BROWN, T. A., \& RAINE. S. Social Conflict and Political Estrangement, 1958-1972. Paper delivered at 1973 Midwest Political Science Association Convention, 1973.

SCHUMAN, H. \& HATCHETT, S. Black Racial Attitudes: Trends and Complexities. Ann Arbor, Mich.: Institute for Social Research. Universiry of Michigan. 1974.

WITHEY, S. B., \& ANDREWS, F. M. Social Indicators of Well Being. New York: Plenum, 1976. 